\title{
Article \\ Analyzing the Societal Cost of Electric Roads Compared to Batteries and Oil for All Forms of Road Transport
}

\author{
Hasan Huseyin Coban ${ }^{1, * \mathbb{C}}$, Aysha Rehman ${ }^{2} \mathbb{D}$ and Abdullah Mohamed $^{3}$ \\ 1 Department of Electrical Engineering, Ardahan University, Ardahan 75002, Turkey \\ 2 Department of Mathematics, University of Gujrat, Gujrat 50700, Pakistan; aysharehman1986@gmail.com \\ 3 University Research Centre, Future University in Egypt, New Cairo 11745, Egypt; mohamed.a@fue.edu.eg \\ * Correspondence: huseyincoban@ardahan.edu.tr
}

check for updates

Citation: Coban, H.H.; Rehman, A.; Mohamed, A. Analyzing the Societal Cost of Electric Roads Compared to Batteries and Oil for All Forms of Road Transport. Energies 2022, 15 , 1925. https://doi.org/10.3390/ en15051925

Academic Editor: Mario Marchesoni

Received: 7 February 2022

Accepted: 2 March 2022

Published: 6 March 2022

Publisher's Note: MDPI stays neutral with regard to jurisdictional claims in published maps and institutional affiliations.

Copyright: (C) 2022 by the authors. Licensee MDPI, Basel, Switzerland. This article is an open access article distributed under the terms and conditions of the Creative Commons Attribution (CC BY) license (https:// creativecommons.org/licenses/by/ $4.0 /)$.

\begin{abstract}
This article is designed to demonstrate that electric roads are an affordable way to electrify all forms of road transport-not only cars, but also buses and trucks. Electric roads represent a way to power electric vehicles without relying solely on batteries. The idea is that when an electric vehicle reaches an electric road, it stops using power from the battery and instead uses power directly from the road itself. The primary challenge for electric vehicles is still the perception of a compromised quality of life in owning an electric vehicle due to a limited range compared with petrol and diesel cars, today. This paper introduces a new technology, currently experiencing rapid development, that can not only overcome range anxiety but make electric vehicles better, in terms of range, than petrol and diesel cars today. Furthermore, not only can this research help to arrange this, but it can also help, for the first time, to cost-effectively electrify heavy-duty transport, such as trucks and buses, which would be a huge breakthrough in terms of sustainability, as it is very important to start supplying electricity to heavy-duty vehicles. The case study provides a very hypothetical example of a trip with and without an electric road, covering a total of $26,011 \mathrm{~km}$ of highways and main roads. The results indicate that building electric roads is cheaper than many other alternatives. If a large battery is replaced with a smaller battery for each new vehicle sold, after 3 years, enough savings will be made to electrify all highways and main roads in Turkey. This paper can help transport operators and policymakers develop strategies to accelerate the adoption of electric vehicles by appropriately implementing electric road infrastructure.
\end{abstract}

Keywords: electric road system; battery-electric car; electric vehicle; sustainable transport; profitability; charging infrastructure; optimization algorithm

\section{Introduction}

The horse and buggy had still reigned supreme as the mode of transportation of choice, but a relative newcomer, the automobile, was about to become all the rage in the early 1900s. Then, roads began to be paved, and features such as gas stations and traffic lights appeared. Everything looked different; the transition from horse to horsepower ushered in a complete infrastructural change that rippled through every sector imaginable and made our modern world possible. A century later, are we on the cusp of another transformation of magnitude? Today, the world pretty much agrees on the basic idea that it needs to cease using fossil fuels and move toward more sustainable solutions to modern needs [1].

Energy is the most strategic sector affecting a country's security and foreign policy and it requires long-term decisions. Since the beginning of the 21st century, the world has been witnessing a shift from hydrocarbon sources to sustainable clean energy sources in the energy age. Energy determines the strategies of international actors, and Turkey aims to be an energy center [2].

In terms of natural gas and oil needs, it needs to cease its dependence on, especially, Russia and Middle Eastern countries. In 2013, the official website of the Ministry of Foreign 
Affairs focused on four basic elements upon which Turkey's energy strategy would be based: diversification of source countries and routes; increasing the share of renewable energy in meeting energy needs; starting to benefit from nuclear energy; increasing energy efficiency; and contributing to Europe's energy security [3,4].

Transport is a big part of today's society. Cars emit large amounts of carbon dioxide $\left(\mathrm{CO}_{2}\right)$, which contributes to the greenhouse effect and global warming. The transportation industry accounts for approximately $27 \%$ of global greenhouse gas emissions [5], one of the largest contributors to pollution in the world. The average temperature of Earth is increasing and there is talk of reaching the $2{ }^{\circ} \mathrm{C}$ limit-if the average temperature of the earth exceeds this figure, the side effects will be very noticeable [6]. By reducing the use of petrol-powered cars, $\mathrm{CO}_{2}$ emissions are reduced [7].

How is it possible to move with the ease and freedom that internal combustion engines offer while successfully reducing our overall carbon footprint? To achieve this goal-the use of electric vehicles-decarbonization strategies should include the electrification of public transport and heavy-duty trucks and vehicle technology that increases the use of renewable energy [8]. However, using electric roads is not a simple panacea for the world's climate problem. There is a need to understand that electric vehicles are very good, but, batteries themselves are not so green $[9,10]$.

The more electric vehicles are utilized, the more electricity is consumed, and electricity is powered by polluting materials such as natural gas or coal. As with the transition from horse to horsepower between the 19th and 20th centuries, the established infrastructure may need to change. Many unresolved issues remain, such as that there are not enough lithium ion and cobalt resources in the world, today [11]. For every kilometer travelled, batteries become heavier, which then drains them faster, forcing people to stop and charge again and again, which consumes energy; people are left with the ultimate riddle. With steady support from leading automakers and governments in the face of the COVID-19 crisis, the global market share of electrified light vehicles (mainly SUVs and cars) grew from $8 \%$, in 2019 , to $12 \%$ in 2020 . It is expected that electric vehicles will account for $15 \%$ of new light vehicle sales over the next 7 years [12].

For Turkey to achieve its goal of becoming fossil fuel-independent, it needs to find a cost-effective solution to use renewable energy sources for road transport without significantly changing the driving patterns of private and commercial vehicles. Moreover, since the transportation sector accounts for $67 \%$ of the total energy consumption produced from non-renewable resources in Turkey, such a transition will have a significant impact on the fossil fuel consumption in the country, improving local air quality in cities and reducing $\mathrm{CO}_{2}$ emissions from energy production and consumption [13].

Since fossil fuels are not used in electric vehicle systems and there is no need for an internal combustion engine to burn fuel, these systems are both more environmentally friendly and more economical $[14,15]$. However, for electric vehicles to compete with conventional vehicles, low cost [16], driving range [17], and full charging range [18] criteria must reach desired levels [19]. Electric vehicles are much less costly and easier to maintain than internal combustion engine vehicles, as they do not need oil changes, do not have periodic maintenance costs, eliminate various maintenance costs specific to traditional engines, and have fewer parts to wear out. Owning an electric car provides significant savings, in the long run.

The electric vehicles that are on the market today typically have a range of around $300 \mathrm{~km}$ [20]. The Tesla Model S may be an exception, but it cannot be categorized as affordable [21]. During a travel distance of $1000 \mathrm{~km}$, today, one has to stop perhaps three or four times along the way to charge the electric vehicle. For most people, that is a disadvantage, because people are used to considering a diesel car, which travels about $800 \mathrm{~km}$ before requiring filling up. A $300-\mathrm{km}$ range electric vehicle uses onboard storage from its starting point to the electric road. Then, once the vehicle gets to the electric road, it connects directly to the road and uses the electricity from the road to power the vehicle, traveling another $1000 \mathrm{~km}$. The vehicle leaves the road with a fully charged battery on 
board and travels $300 \mathrm{~km}$ anywhere around the city area. Thus, should electric roads be in place, it can be ensured that electric cars provide a better quality of life than do diesel and gasoline cars [22]. Secondly, heavy-duty trucks can only be conceivably powered by electricity. Here, electric roads provide electricity for a huge fraction of a journey for heavyduty vehicles, such as buses or trucks, assuming electricity in place [23]. Additionally, based on original product manufacturer data collected in the literature, it has been shown that the average period for which automobile manufacturers will warrant high-voltage lithium ion batteries is 8 years for cars and 4 years for trucks and buses [24].

Over the last decade, one of the most interesting things to observe has been the introduction of the Model S, from Tesla [21]. If manufacturers can provide a higher quality product than people have had in the past, then people are more than happy to move from petrol and diesel to electric vehicles. The Model $S$ has demonstrated that a better quality of product is something people are willing to pay a lot of money for even though it is an electric car.

One of the most important factors creating cost in electric vehicles are battery packs [25]. Therefore, studies [26-28] on electric vehicles have mostly focused on batteries. Battery technologies are under development, and the problems of battery cost and the driving distance of electric vehicles are in the process of being eliminated.

The concept is to strategically place electric roads in cities and on main roads such that vehicles can be charged during use, regardless of whether the vehicle is in static or dynamic mode [29]. This means that the car can run on continuously without having to stop to charge [30]. Moreover, charging while driving is both time-saving and economical as the petrol station becomes completely redundant. Within this context, electric road systems are an alternative for overcoming the main disadvantages and eliminating the range problem of the batteries of electric vehicles and the charging of these batteries and heavy vehicles while driving [31]. The other area that can heavily benefit from electrified roads is the transport sector. The highways today are greatly trafficked by heavy trucks; if they could run on electricity, the environmental and the economic gains for haulage contractors, would be enormous. Since electric road systems are expected to be used on highways and main roads, a green solution is presented by reducing the required battery capacity in vehicles. The question of how to create a charging solution where the car battery can be as small as possible remains. Considering the battery capacity and battery density, not every vehicle needs a large battery; not every vehicle needs to travel hundreds of kilometers. Consequently, the vision is to empower the transition to electric vehicles most sustainably and as efficiently as possible whilst ultimately lowering the cost of ownership of the vehicles owners.

Despite these many advantages of electrified roads, it is necessary to evaluate different technologies to determine which are the most economically and technically feasible for Turkey, as the implementation of a nationwide electric road system requires significant investment. Such study should take into account the existing road network, the composition of the country's land vehicle fleet, and usage patterns [31]. It should be considered that there is much cost on the vehicle side and the infrastructure side in the transition to electrified roads. Studies investigating the societal cost of electrifying all road transport with different electric road systems technologies (wired and wireless) have already been carried out for the cases of Denmark [31] and Sweden [32,33].

The scientific literature, in recent years, has generally investigated electrified road systems in terms of technology. Some articles have studied a three-phase inductive power transfer system [34], advantages of inductively coupled power transfer [35], and the maturity of ER (electric road) technologies [36]. Some articles [37,38] have the demonstrated ERSs (electric road system) offer better possibilities in electric power demand for roads. For example, ERSs have been investigated in terms of electricity demand in Norway [38] and the Netherlands [37]. In some other articles [39,40], the environmental performances of ERSs and EVs and their effects on total energy use and greenhouse gas emissions have been investigated; they depend on the fuel mixture used to generate the necessary electrical 
energy to power the ER vehicles. In addition, different aspects of ERSs were evaluated in some other reports [31,41-44]. Some studies have investigated ERSs in terms of a feasibility study [45,46], costs [31], $\mathrm{CO}_{2}$ emissions [31], and technical aspects [47]. Following these articles, this paper aims to explore the societal cost of electrifying road transport on Turkish highways and main roads with and without ERS.

In this study, it is observed that the cost savings of owning a fleet of smaller batterypack vehicles greatly exceeds the cost of installing an electric road system infrastructure in which most vehicle types can benefit. This result confirms that a much lower equivalent cost of electrified roads is achieved when the infrastructure cost is shared among all vehicles. Installing the technology means vehicles' battery capacities can be massively reduced, which can reduce the cost of the vehicles themselves. Vehicles never need to stop to charge again, and they can be charged with different amounts of energy in different vehicles on the same platform. In this study, we develop alternative scenarios for large-battery, electric vehicles and fuel vehicles, mainly since such alternatives will reduce foreign energy dependency in countries such as Turkey, as electric vehicles save much more fuel than vehicles with internal combustion engines, thereby providing a significant reduction in carbon emissions caused by heavy traffic. If the price of the batteries is low enough it will overcome of the important problem of the weight of large batteries, which is a significant part of the total load of the vehicles, since electric vehicles are much more fuel-efficient than vehicles with internal combustion engines. Using this against investment costs can produce a cost-benefit analysis.

The remainder of the article is organized as follows:

Section 2 summarizes the ERS principle and technology. Additionally, studies related to the ERS in the use and the project phases are introduced. In Section 3, cost modeling, assumptions, measurement, and payment system for Turkey are presented. In Section 4, electrified road scenarios and vehicle fleet scenarios are introduced. In addition, a sensitivity analysis of cost and price elasticity for 2040 is made and the results and discussions detailed. Finally, in Section 5, the findings are summarized, and the results are discussed.

\section{The Principle and Technology of ERS}

This section briefly explains how energy in the road area can be extracted and the theory behind how each technology in energy distribution to vehicles. Lithium batteries are heavy and expensive [48]. They require fossil fuels to mine and assemble, and limit an electric vehicle range with their small charge capacity [20,49]. The cost and associated range of batteries is the biggest obstacle to the more widespread adoption of electric vehicles [50]. That is where electric roads come in. Capacity and costs are not the only downsides of batteries, there is also a lack of charging stations, their environmental impact, their reliance on rare-earth metals. The things that rely on batteries in daily life are flashlights, cell phones, and wireless speakers. These are things that are used only for short periods away from a power source. TVs toasters do not work on batteries-nobody would buy a TV that needs to recharge after three hours. Batteries are task-specific; if a product does not need batteries, they are not included. Lithium ion batteries offer short trips; after driving for approximately $300 \mathrm{~km}$, they needs to charge for a couple of hours. Let us start thinking of cars as TVs and give them access to power all the time while using and driving them. The concept is not brand new; it has been happening for over a hundred years. Municipalities have been powering trackless trollies from overhead wires for exactly that long.

A literature study that deals with past, ongoing, and future projects in energy distribution and energy recovery at the roadway has been conducted. According to these criteria, two different main groups and three subgroups can be classified in the literature: wireless and conductive charging electric roads, which in turn include road-bound conductive, overhead conductive, and roadside conductive classifications [44]. 


\subsection{Inductive (Wireless) Charging}

Induction is a way of wirelessly transferring energy between the source and receiver. It is a system that is common in households; induction cookers and cordless phone chargers are examples of this.

Wireless charging is nothing new. Its use has been around almost as long as the discovery of electricity itself. The principle is based on Nikola Tesla's discovery more than 100 years ago. Nikola Tesla was so ahead of his time that his vision for wireless energy transformation was buried by his competitor, Thomas Edison, in favor of a less egalitarian and more capitalistic system of energy transmission. Today, he is practically worshiped by the tech elite and the Tesla coil remains the inspiration for wireless internet connections as well as charging solutions such as electric roads.

The existing solutions based on plug-in charging may not satisfy the transition to electric vehicles alone. Wireless charging, or wireless electric roads, are thought to be technologies that could help accelerate the adoption of electric vehicles [51]. Wireless charging is a way to transmit energy from one coil to the other coil without having a hard connection between the two [44]. The vehicle can be charged while driving, while waiting for passengers inside the city, or while loading goods at the loading dock; it means charging the vehicle almost anytime, anywhere. It is possible to reduce the size of the battery and energy can be delivered almost all day long. It is done with copper coils that are installed under the roadway or wherever charging is deployed, which transfer energy over the air to a receiver installed directly under the vehicle chassis.

This charging can occur even when the car is moving and comes with a holistic power management system to maximize the process. Wireless electric road technology is made up of four major components [52,53].

1. the copper coils, directly under the road;

2. the receiver unit, which accepts the energy from the copper coils and is under the road;

3. that relationship, managed by a management unit at the side of the road that receives energy directly from the grid and then safely transfers it to the copper coils under the road; and

4. the management of these three components by cloud software, which allows the entire relationship to be monitored remotely, ensuring adequate energy is transferred, and ultimately charging and billing the energy.

Although there is no electrical outlet, thanks to the induction plates, which the vehicle stands on, the vehicle can be fully charged during the night. Induction plates could even be built into driveways. Driving on country roads or in the city the vehicle gets its power from the small and light battery. Induction technology comes into play once again when longer distances need to be covered. Driving, onto main roads or motorways one lane has induction power built into it. The car automatically senses the power unit and starts recharging the internal battery once again.

\subsection{Conductive Charging}

Conduction is the opposite of induction, in which energy is transferred through physical contact between the source and the receiver. There are mainly three ways to conductively charge vehicles while driving: a power source above the road; a power source next to the road; or a power source in the road [44]. The two most explored are power sources above the road and in the road. The principle their operation can be compared with electric power running a train; an arm folds out and it is in contact with the power supply while in motion. However, where trains can take electricity from above and transfer it backward via rails, for vehicles on roads, there is no such possibility, as they roll over asphalt or concrete roads with rubber-coated wheels. Thus, conductively charging a vehicle while driving must provide a device that directs the current back to the grid [54]. Another difficulty with conduction - especially with pantographs above the road-is that trucks and cars have large height differences. A car would need a long arm to reach the same 
power line that trucks would take their power from. Conductive technology is available mainly in three different versions [30], described next.

\subsubsection{Overhead Conductive}

The technology is based on the same principle as for electricity transmission to trains on railways. The electricity transmission takes place via an overhead line that is connected to the vehicle via a pantograph mounted on top of the vehicle that can move vertically. The overhead line is located at a height of about $5 \mathrm{~m}$ above the road and is suspended in poles that stand at intervals of about $60 \mathrm{~m}$. The height means that the system with overhead lines comes away from the road surface, but also that it is only suitable for larger vehicles such as trucks and buses, not for passenger cars $[44,55]$.

In particular, conductive charging above the road should be used along sections where there is regular heavy traffic. Modern trucks can be fitted with an electric engine and a roof-mounted pantograph. When driving on a motorway this pantograph is hoisted up towards an overhead electric wire suspended from roadside posts, thus supplying the electric engine with the necessary electric power [44,55]. Buses and trucks that travel the same route every day between factories and ports are a good example for this. The Swedish project at the Aitik mine, where heavy trucks travel the same route in the open pit every day get their energy supply from conductive lines [56].

\subsubsection{Road-Bound Conductive}

Vehicles that use an road-bound conductive electric roads have receivers that are lowered into a rail. The upper part of the rail is flush with the road surface and must meet the same friction requirements as the road. Conductive electric road technology is available in two versions $[44,57]$.

In the first one, there are two separate tracks in the rail. The opening in each groove is about $2 \mathrm{~cm}$. The contact surfaces are immersed about $6 \mathrm{~cm}$ to $10 \mathrm{~cm}$ into the road surface. Under the vehicle is an energy receiver that automatically connects to the electric road system when it has been detected. The energy receiver on the vehicle consists of a mechanical arm that can be moved both vertically and sideways.

The second one is a rail mounted on top of the roadway, part of which is immersed into the roadway. Beyond the difference in installation, these variants are functionally identical. They mainly consist of an aluminum profile that holds the earth's potential. Inside it is a voltage-carrying rail that holds the supply potential and contact rails in the middle/top edge. The top rail is designed as a triangle, $30 \mathrm{~cm}$ wide and $3.5 \mathrm{~cm}$ high. The contact rails for the receiver on the vehicle are exposed at the top of the rail. Both the positive and negative contacts are in the same line and are separated into $1 \mathrm{~m}$ sections by $15-\mathrm{cm}-$ long insulation rails. The rail must meet the requirements for friction on the road [58].

\subsubsection{Roadside Conductive}

In this method, the conductor is not limited to being placed above or below the vehicle in the electrified road system. The Japanese manufacturer Honda proposes this different alternative, in which they place the transmitting power lines to the side of the road [55,59]. This allows both passenger and heavy-duty vehicles to take advantage of the infrastructure without changing lanes on the road. This can potentially mean lower maintenance costs for the road and lower installation cost for the ERS. It can extend a mechanical arm or pantograph from the side of the car to slide on a conducting rail on the road barrier for charging. Although this system has been tested at driving speeds between 5 and $156 \mathrm{~km} / \mathrm{h}$ and transmission powers of up to $180 \mathrm{~kW}$, further testing on public roads is necessary to ensure the reliability and safety of the system [55]. All the mentioned electric road system technologies are depicted in Figure 1. 


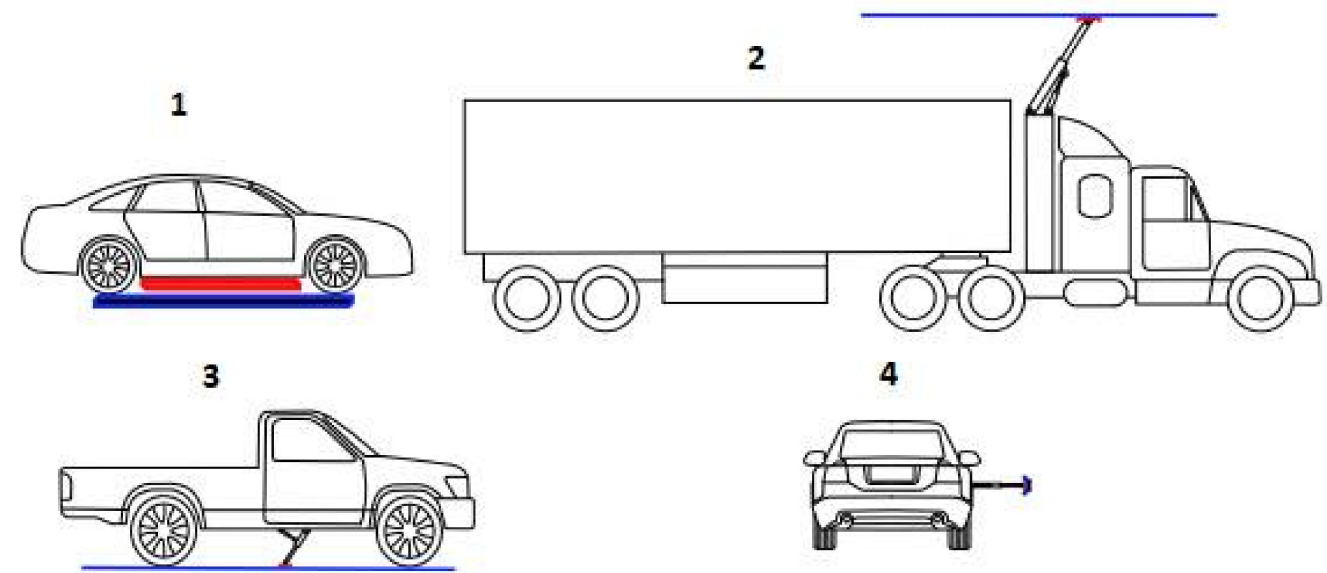

Figure 1. Different concepts for electrifying roads investigated in this study. 1. Road-bound inductive; 2. overhead conductive; 3 . road-bound conductive; 4 . roadside conductive [55].

Inductive and conductive system solutions have many advantages and disadvantages compared with each other. The most important advantage conductive systems have over inductive systems is that higher power can be reached relatively easily, while, in inductive charging, the conductor isolates the vehicle from the supply, which is an important safety feature. Regarding safety, the conductive solution to energy transfer is more difficult than the inductive method, as exposed live parts are unavoidable. Another disadvantage of conductive energy transfer is mechanical wear, which requires a certain degree of maintenance and exposure to the elements over inductive solutions [60].

In the next sections of this paper, only conductive ERS technologies are considered, because they are the most mature, popular, and the ones about which most of the experimental research has been carried out.

\subsection{Electric Roads Internationally}

As electric vehicles become increasingly prominent on roads and charging capacity increasingly an issue, countries need to find broad solutions for their fleets of vehicles. There are several studies and test activities concerning electric roads around the world. Current developments for conductive and inductive road technologies are summarized in Table 1. Some technical conditions in the electric road system are summarized below. The summary includes the three main techniques that have been tested in the world.

Sweden [32,33,44,55]: Since 2017, Sweden has been conducting an innovation partnership with Germany, wherein electric roads are one of four areas of cooperation. Since 2019, Sweden also has had an innovation partnership with France, part of which concerns electric roads. The Swedish Transport Administration has been tasked with coordinating both of these partnerships. The project in Gotland, Sweden where the charging of a 40-ton, large truck and a large electric bus have shown the capacity for battery reduction.

Germany [61,62]: In Germany, work on electric roads has been going on for over 10 years, mainly through Siemens' development of electric roads with overhead lines. On three sections of public roads, this technology is now being tested with trucks delivered from Scania. In Karlsruhe, a 100-m-long section of inductive electric road, from the company Electreon, has been installed. An electric Higer bus is expected to start running on the route in the spring of 2021. Planning for the next stage, which is a 500-m extension on a public road in Karlsruhe, has begun. In addition, a 100-m electric road is planned at a test facility in Cologne, in collaboration with Volkswagen and Eurovia.

France [63,64]: Renault began looking at the ER idea in 2012, creating a route on the outskirts of Paris that enabled the ongoing charging of two of their Kangoo electric vehicles as they drove. Moreover, in France, an analytical work is underway regarding electric roads that will be presented in the autumn of 2021. The study deals with economic and other aspects of electric roads, various electric road techniques, and suitable test distances. The 
vehicle manufacturer Renault and the company Vedecom develop and test an inductive electric road technology. They are planning demonstration routes to be put into operation in central Paris in the summer of 2022. The power transmission technology is based on a commercially available solution for static inductive charging from the company Qualcomm and has been installed in a Renault Van. The company Bombardier has also tested dynamic inductive power transmission on an 80-m-long closed test track in Mannheim.

UK $[65,66]$ : In the United Kingdom, a feasibility study on electric roads, presented in the summer of 2020, has presented electric roads as a possible technology for reducing $\mathrm{CO}_{2}$ emissions from heavy vehicles. In the summer of 2021, it was decided that a 30-km-long section of the M180 near Scunthorpe would be equipped with overhead lines from Siemens. The project will link the port of Immingham with the Doncaster Logistics Center and airport. It is funded by the British government to test zero-emission solutions for freight transport.

United States $[67,68]$ : There are a couple of interesting electric road projects under development in the US, one, in Indiana, and another one in Michigan. Purdue University in Indiana is collaborating with the state to develop a pilot stretch of roadway built with magnetizable concrete. The Michigan project is only at the request-for-proposal stage, which plans to have it running by the end of 2025. In the spring of 2021, the US Federal Transport Administration decided to grant permission for tests of electric road technicians on public roads. In the USA, five universities have collaborated in the SELECT project on inductive technology. Siemens has also conducted tests of its conductive technology in the United States, in 2017, on a 1.6-km-long road in an industrial area near the port outside Los Angeles. The work was carried out under the direction of the South Coast Air Quality Management District.

China [69]: In China, players have taken an interest in static and dynamic inductive electric road technologies and solar roads. An inductive electric road has existed as a 2-km-long test facility since 2016. There are plans for extensive test activities, with a maximum length of $45 \mathrm{~km}$.

Finland [70]: A Finnish clean energy company, Thornton, through their charge and drive program, with major car firms like Jaguar and Land Rover, are also stepping up to wireless plates; the very first step is expected to be active in 2023.

Norway [71,72]: The Scandinavian country Norway has already committed to requiring all new cars sold to be electric by 2025 [73]. Norway also intends to build an entirely emission-free taxi service to assist in its lofty aims. With charging time and efficiency being limiting factors for electric commercial vehicles in particular they will be doing this by charging the cabs wirelessly through the taxi rank they sit on, as the taxis wait to be hired. This saves in several ways; there is no need to hunt out an available charger, no need to wait separately for a charge, and no need to plug in or unplug. The charging will allow up to $75 \mathrm{~kW}$, entirely without cables.

Table 1. Overview of functions in different electric road techniques identified.

\begin{tabular}{|c|c|c|c|c|c|}
\hline Name & Reference & Country & Type of ERS & Company & Type of Vehicles Considered \\
\hline Sandviken & \multirow{4}{*}{ [58] } & \multirow{4}{*}{ Sweden } & overhead & Siemens & $\begin{array}{c}\text { for heavy-duty trucks; it was } \\
\text { inaugurated in } 2016\end{array}$ \\
\hline Arlanda & & & road-bound & Elways & $\begin{array}{l}\text { all road vehicles; it was } \\
\text { inaugurated in } 2018\end{array}$ \\
\hline Lund & & & road-bound & Elonroad & $\begin{array}{c}\text { The project will be built in a bus } \\
\text { lane along } 1 \mathrm{~km} \text {. The project's } \\
\text { budget is } 9.3 \mathrm{M} €\end{array}$ \\
\hline Visby & & & inductive & Electreon Wireless & $\begin{array}{l}1.6-\mathrm{km} \text { test section between the } \\
\text { airport and the center of the city } \\
\text { of Visby }\end{array}$ \\
\hline
\end{tabular}


Table 1. Cont.

\begin{tabular}{|c|c|c|c|c|c|}
\hline Name & Reference & Country & Type of ERS & Company & Type of Vehicles Considered \\
\hline Los Angeles & [67] & USA & overhead & Siemens & $\begin{array}{l}\text { for heavy-duty trucks; } \\
\text { inaugurated } 2017\end{array}$ \\
\hline \multirow[t]{2}{*}{ eHighway } & {$[61]$} & \multirow{3}{*}{ Germany } & overhead & Siemens & heavily used truck routes, 2017 \\
\hline & [62] & & inductive & Eurovia and ElectReon & $\begin{array}{c}100 \mathrm{~m} \text { (90 m of dynamic load/ } \\
10 \mathrm{~m} \text { of static load) }\end{array}$ \\
\hline Cologne & [62] & & inductive & ElectReon & $\begin{array}{l}\text { a Volkswagen electric vehicle to } \\
\text { be tested on an electric road }\end{array}$ \\
\hline Paris & {$[63,64]$} & France & inductive & $\begin{array}{l}\text { Renault partners with } \\
\text { Qualcomm Technologies } \\
\text { and Vedecom }\end{array}$ & $\begin{array}{l}\text { charge of up to } 20 \mathrm{~kW} \text { at speeds } \\
\text { up to, and above } 100 \mathrm{~km} / \mathrm{h}\end{array}$ \\
\hline Smart road & [58] & Israel & inductive & ElectReon & $\begin{array}{l}\text { powers } 200 \text { public buses at } \\
\text { city terminals }\end{array}$ \\
\hline Scunthorpe & {$[66]$} & UK & overhead & Arcola Energy & $\begin{array}{l}\text { overhead, } 20-\mathrm{km} \text { stretch of the } \\
\text { M180; the trucks could be on the } \\
\text { road by } 2024\end{array}$ \\
\hline Shandong & [69] & China & inductive & $\begin{array}{l}\text { Qilu Transportation } \\
\text { Development }\end{array}$ & $\begin{array}{c}\text { 2-km stretch of } \\
\text { solar-powered highway }\end{array}$ \\
\hline OLEV & [74] & South Korea & inductive & OLEV & for electric buses \\
\hline
\end{tabular}

\section{The Turkish Case}

As of the end of June 2021, the total number of registered vehicles in Turkey was 24.7 million. These vehicles consist of $54.3 \%$ cars, $16.3 \%$ pickup trucks, $14.6 \%$ motorcycles, $8.1 \%$ tractors, $3.5 \%$ trucks, $2.0 \%$ minibuses, $0.9 \%$ buses, and $0.3 \%$ special-purpose vehicles [75].

Vehicles in the car segment travel relatively shorter distances compared with other segments. Second-segment vehicles are characterized by a high utilization but a low average driving speed, as all buses use the city lines. Distribution trucks with a combined gross weight rating of 3.6 to 16 tons form the third segment; these vehicles are widely used on both urban and intercity routes. The fourth segment consists of heavy vehicles used for long-haul transport, including buses and trucks.

The societal cost of electrifying a nation's entire vehicle fleet depends not only on fleet composition but also on road network expansion and the driving patterns of the population. As shown in Figure 2, Turkey's surface area is $783,562 \mathrm{~km}^{2}$ [76]. As of the end of 2020, the length of the highways in Turkey is $3523 \mathrm{~km}$ and of the divided roads is $27,470 \mathrm{~km}$ [77]. The Turkish transport sector's detailed breakdown is summarized in Table 2 [78].

Table 2. Vehicle cost assumptions and detailed breakdown of the Turkish transport sector for 2021.

\begin{tabular}{|c|c|c|c|c|c|c|}
\hline Vehicle Type & Cars & Vans and Minibus & Motorcycles & Tractors & Trucks & Buses \\
\hline road vehicles (\%) & $54.30 \%$ & $18.30 \%$ & $14.60 \%$ & $8.10 \%$ & $3.50 \%$ & $0.90 \%$ \\
\hline number of road vehicles & $13,428,336$ & $4,525,572$ & $3,610,566$ & $2,003,122$ & 865,547 & 222,569 \\
\hline average annual mileage $(\mathrm{km})$ & 15,000 & 20,000 & 4000 & NA & 75,000 & 58,000 \\
\hline $\begin{array}{l}\text { average fuel consumption } \\
\qquad(1 / 100 \mathrm{~km})\end{array}$ & 7 & 10 & 2 & & 28.5 & 20.5 \\
\hline $\begin{array}{l}\text { average fuel consumption } \\
(\mathrm{kWh} / 100 \mathrm{~km})\end{array}$ & 19.8 & 32.1 & 4.0 & - & 121.8 & 82.5 \\
\hline transport demand (Mkm) & 201,425 & 90,511 & 14,442 & NA & 64,916 & 12,909 \\
\hline investment (\$/vehicle) & & 20,000 & 3000 & 20,000 & 99,220 & 177,184 \\
\hline
\end{tabular}


Table 2. Cont.

\begin{tabular}{|c|c|c|c|c|c|c|}
\hline Vehicle Type & Cars & Vans and Minibus & Motorcycles & Tractors & Trucks & Buses \\
\hline $\begin{array}{l}\text { annual } \mathrm{O} \text { and } \mathrm{M} \\
\text { (\% of invest) }\end{array}$ & & $4.10 \%$ & $3.50 \%$ & $6 \%$ & $21.10 \%$ & $9.10 \%$ \\
\hline lifetime (years) & & 16 & 20 & 20 & 10 & 10 \\
\hline vehicle efficiency $(\mathrm{kWh} / \mathrm{km})$ & 0.7 & 1.3 & 0.2 & NA & 10.7 & 6.5 \\
\hline $\begin{array}{l}\text { transport fuel consumption } \\
\text { (TWh/year) }\end{array}$ & 39,882 & 29,054 & 577.690 & NA & 79,068 & 10,650 \\
\hline
\end{tabular}

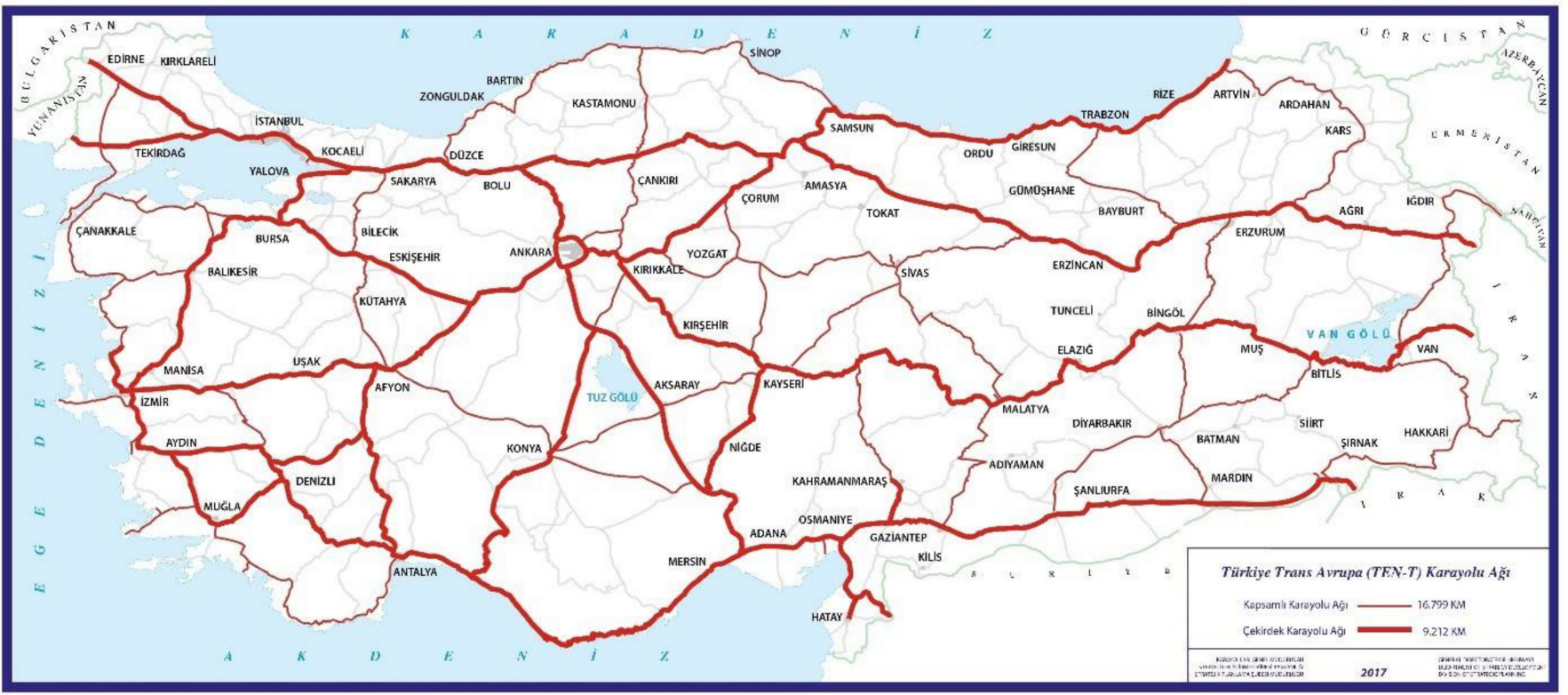

Figure 2. ERS map of Turkey, which is examined in this study [79].

\subsection{Cost Modeling and Assumptions}

To assess the societal cost of electrifying road transport in various scenarios, it is necessary to consider the low energy consumption of electric vehicles, the additional electromobility associated with onboard components, and the necessary investments in charging infrastructure.

When modeling ERS infrastructure it is necessary to account for costs of operating and the maintenance costs of control and monitoring systems, network fees, operation and maintenance costs for the electric road system, the increased cost of road maintenance, the cost for energy losses in the electric road system, electricity cost, energy tax, and the cost of electricity administration, the operating and maintenance costs of user authorization and fee systems, such as measurement values and invoicing.

The cost of ERS infrastructure is modeled based on results from pilot test data in the literature (Denmark and Sweden), conductive solutions, and approximate estimated installation costs [43].

Since electric road systems are relatively new technologies, it is useful to keep in mind that it is difficult to obtain cost estimates because the projects are unique and not in the mass production-type as in the production sector, due to not having been standardized yet.

Besides the cost of the electrified road system, Li-ion batteries also add uncertainty to the total system cost estimates presented. The cost of Li-ion batteries used in electric vehicles is known, at approximately $\$ 175-300$ per kilowatt-hour [43,80]. With innovations in energy and batteries, these costs are expected to come down to $\$ 100$ per kilowatt-hour in the future [80]. Researchers working on electric vehicle technology emphasize that this 
figure will play an important role in bringing electric vehicles to the same level as the fossil fuel vehicle market. In this study, a figure of $\$ 100 / \mathrm{kWh}$ was used.

In addition, electricity and fuel prices are assumed to be $\$ 0.059 / \mathrm{kWh}$ and $\$ 1.09 /$ liter including VAT, according to current figures in Turkey. The lifetime of the conductive charging system is assumed to be 15 years for all items [81]. The key assumptions are summarized in Table 3. Finally, profits and overheads costs are not taken into account, as the aim of this study is to estimate the societal cost of electrifying highways and major roads over different scenarios.

Table 3. Key assumptions for ER infrastructure in this study, based on a conductive charging system.

\begin{tabular}{|c|c|c|}
\hline \multicolumn{2}{|c|}{ Total ERS Installed (One Way) } & $26,011 \mathrm{~km}$ \\
\hline \multicolumn{2}{|c|}{ Lifetime of ERS } & 15 Years \\
\hline \multirow{2}{*}{$\begin{array}{l}\text { ERS investment for a full installation, } \\
\text { including electric grid costs (One Way) }\end{array}$} & overhead electric road & $\$ 1.1 \mathrm{M}$ \\
\hline & road-bound conductive & $\$ 0.7 \mathrm{M}$ \\
\hline \multicolumn{2}{|c|}{ interest rate } & $4 \%$ \\
\hline \multicolumn{2}{|c|}{ fixed $\mathrm{O}$ and $\mathrm{M}$ (per $\mathrm{km}$ ) } & $\$ 16,000$ \\
\hline \multicolumn{2}{|c|}{ conversion cost to ERS for cars and vans } & $\$ 2000$ \\
\hline \multicolumn{2}{|c|}{ conversion cost to ERS for buses and trucks } & $\$ 10,000$ \\
\hline
\end{tabular}

\subsection{Measurement and Payment System}

One issue that has arisen in very few previous studies and has not been properly addressed is how the energy used by vehicles should be paid for. Pricing of the user fee can be adjusted for the socioeconomically efficient use of the electric road according to the capacity of the energy system and the time of day. The user fee can be differentiated at different times of the day to reduce the load on the country's electricity grid. Measurement of electricity transmission can take place either in the vehicle or in the electric road system. Advantageously, when the measurement of data takes place inside the vehicle, it is sent directly to the electrified road system via the GSM network. With charging during travel, it will be different compared to today's stationary charging and refueling where payment is made before departure. When using charging systems for road transport, safe, individual payment of consumed electricity should be possible. On the other hand, such a system should be well protected from IT attacks so that aftermarket gadgets cannot be sold that enable a kind of anonymous driving, where used electricity is not registered.

\section{Scenarios and Results}

The societal cost of all Turkish highways under four different scenarios and the electrification of the automotive fleet is studied under six different scenarios.

\subsection{Electric Road Scenarios}

Overhead electric road: This scenario creates overhead electric road systems of $26,011 \mathrm{~km}$ of main roads in the country for the benefit of trucks and buses. Vehicles will only have enough battery capacity to drive $70 \mathrm{~km}$.

Road-bound conductive: In the second scenario, the overhead electric road system is replaced by a conductive solution, which is not an overhead line but a road-bound solution that is expected to be less expensive in terms of infrastructure. Both cars and trucks can receive the energy directly from the road, consequently, the total battery capacity is significantly reduced. Vehicles will only have enough battery capacity to drive $70 \mathrm{~km}$.

Roadside conductive: Other than the systems mentioned above, side charging means that an arm is pointing to the side of the vehicle. While this alternative is very dangerous for pedestrians and cyclists, it provides lower maintenance and installation complexity. Vehicles will only have enough battery capacity to drive $70 \mathrm{~km}$. 
Road-bound inductive: The conductive scenarios mentioned above are replaced by an inductive-path, coupled solution. As vehicles can be charged while driving on all major roads, battery capacities can be reduced to provide a driving range of approximately $70 \mathrm{~km}$.

Due to the uncertainty of the infrastructure investment cost and the fact that this study did not explore a specific path, three cost levels have been chosen to explore: the overhead electric road of infrastructure $\$ 1.1 \mathrm{M} / \mathrm{km}$, road-bound conductive cost $\$ 0.7 \mathrm{M} / \mathrm{km}$, roadside conductive cost $\$ 1 \mathrm{M} / \mathrm{km}$, and the road-bound inductive costs $\$ 2.2 \mathrm{M} / \mathrm{km}$. In the literature, it is estimated that the maintenance cost is $1-2.5 \%$ of the initial infrastructure investment cost. Overhead electric road, road-bound conductive, roadside conductive, and road-bound inductive maintenance and repair costs are assumed to be $\$ 16,000 / \mathrm{km}$, $\$ 11,000 / \mathrm{km}, \$ 15,000 / \mathrm{km}$, and $\$ 33,000 / \mathrm{km}$, respectively $[43,46]$. Figure 3 shows the total investment and maintenance cost for $26,011 \mathrm{~km}$ of ERS infrastructure.

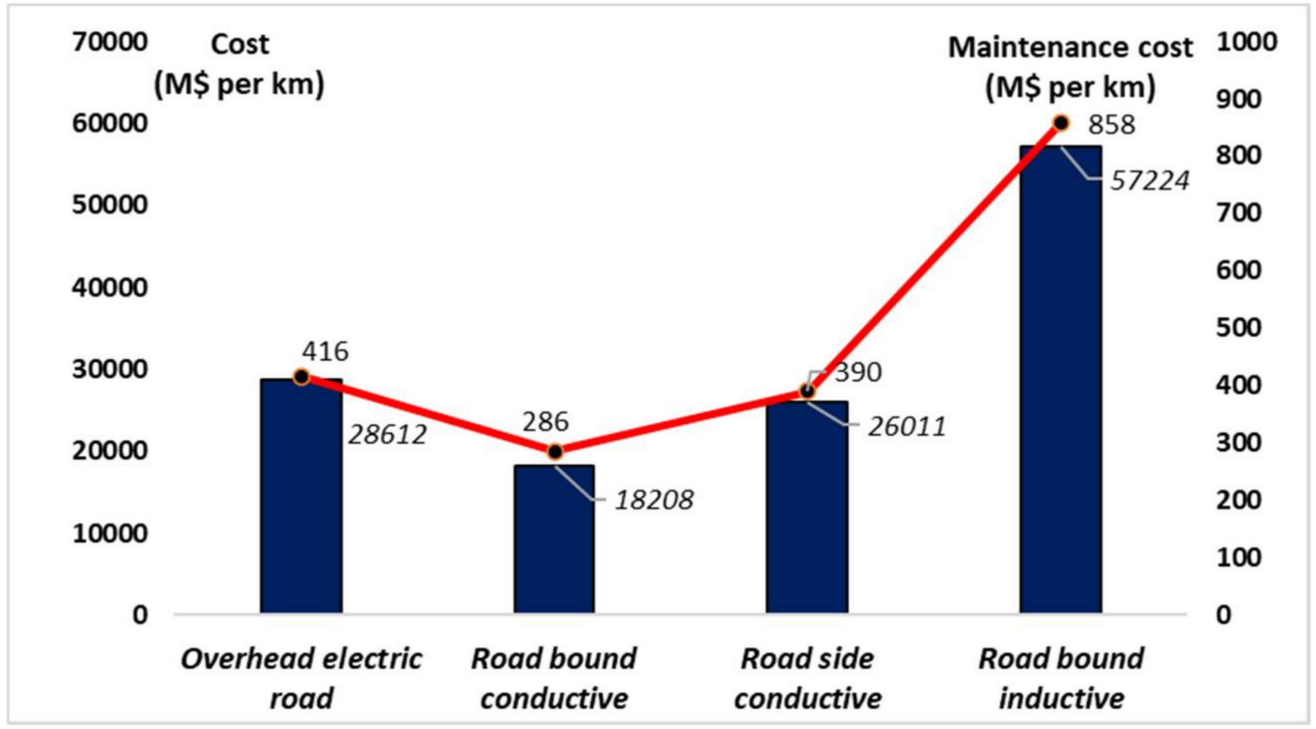

Figure 3. Total investment and maintenance cost to install 26,011 km of ERS in Turkey.

The gross domestic product (GDP) in Turkey was worth \$869.7 B and \$720.1 B in 2016 and 2020, respectively, according to official data from the World Bank [82]. The total cost for implementing ERS is \$18.2 B.

\subsection{Vehicle Fleet Scenarios}

With the detailed breakdown of the Turkish transport sector in Table 2, it is possible to develop various scenarios for the transport sector and thus compare electric roads with battery-powered electric vehicles with conventional fuel types diesel and gasoline.

In the first scenario, it is assumed that existing vehicles continue to use diesel and gasoline. In the second scenario, the electrification of road transport is provided by batteries only. As a penetration rate defined for electric vehicles, it is assumed that $50 \%$ of existing cars, vans, buses, and trucks are converted to battery electric vehicles. Vehicles weighing up to 2 tons are assumed to have sufficient battery capacity to travel $300 \mathrm{~km}$, and a network of $400 \mathrm{~V}$, $125 \mathrm{~A}, 50 \mathrm{~kW}$, typical medium-power DC charging stations are installed across the country. Trucks and buses used in the city are assumed to have a battery range of $300 \mathrm{kWh}$ and $450 \mathrm{kWh}$, respectively, to cover a full day. Long-distance trucks assume a battery capacity of $500 \mathrm{kWh}$ and can travel $200 \mathrm{~km}$; however, waiting $40 \mathrm{~min}$ for charging is unrealistic. To avoid this, replacing the truck with a fully charged one has been implemented for this scenario, although this represents additional cost. In the third scenario, all vehicles in Scenario 2 were converted to battery electric vehicles.

In Scenario 4, it is assumed that the vehicles in Scenario 2 are converted to electric road vehicles with the same battery capacities. In Scenario 5, it is assumed that $100 \%$ 
of the vehicles in Scenario 4 are converted to electric road vehicles. In Scenario 6, it is assumed that the battery capacities of the vehicles in Scenario 4 are reduced to $70 \mathrm{~km}$ and converted to electric road vehicles. In Scenario 7, it is calculated that $100 \%$ of the vehicles are converted to ER vehicles.

The list of scenarios implemented in this study is summarized in Table 4 with a brief description of each scenario. This study aims to analyze the long-term economic impact of the ERS application by making a feasibility study. For this reason, conversion penetrations are considered in $50 \%$ or $100 \%$ of existing vehicles.

Table 4. Summary of the scenarios analyzed in this study.

\begin{tabular}{|c|c|c|}
\hline Number & Scenario Name & Description of the Scenario \\
\hline S1 & petrol vehicles & $99.9 \%$ of the diesel and petrol vehicles \\
\hline S2 & battery electric vehicles & $\begin{array}{l}50 \% \text { of the cars, vans, buses, and trucks are } \\
\text { converted to battery electric vehicles } \\
100 \% \text { of the cars, vans, buses, and trucks are } \\
\text { converted to battery electric vehicles }\end{array}$ \\
\hline S5 & ER vehicles (big battery) & $\begin{array}{c}50 \% \text { of the cars, vans, buses, and trucks are } \\
\text { converted to ER vehicles } \\
100 \% \text { of the cars, vans, buses, and trucks are } \\
\text { converted to ER vehicles }\end{array}$ \\
\hline S7 & ER vehicles (small battery) & $\begin{array}{l}50 \% \text { of the cars, vans, buses, and trucks are } \\
\text { converted to ER vehicles } \\
100 \% \text { of the cars, vans, buses, and trucks are } \\
\text { converted to ER vehicles }\end{array}$ \\
\hline
\end{tabular}

\subsection{Managerial Implications}

For a detailed calculation, Turkey is used as a case study, comparing not only electric roads with battery electric vehicles or large batteries but also gasoline and diesel vehicles. The two of the most important benefits of all of these are not only affordablility, but also those electric car roads that could facilitate the electrification of heavy-duty transport, such as buses and trucks. That is a significant add-on benefit for cars, but buses and trucks are included in the study. The results of various ERS, fossil fuel, and battery electric vehicle scenarios (Table 3) are shown in Figure 4. The total annual energy cost for all types of land vehicles for Turkey in 2020 is approximately $\$ 48.5 \mathrm{~B} /$ year. Figure 4 also shows the $\mathrm{CO}_{2}$ emissions for each scenario, with the smallest $\mathrm{CO}_{2}$ emissions in Scenario 7. Naturally, the ER process would be of limited green benefit unless the electricity being supplied to the vehicles was already from a green source. Electric cars can be much greener than their petrol equivalent but only where care is taken that the electrical source is better for the environment than the petrol it is replacing. However, Turkey has an ever-improving mix of solar PV, hydro, and wind energy-one of the greenest energy supplies in any country in the world.

As seen in Figure 5, in terms of costs, large battery electric vehicle S2 and S3 scenarios are more expensive than petrol S1 scenarios. However, more importantly, the ERS scenarios are cheaper than the corresponding battery electric vehicle scenarios. For example, if 50\% of all vehicles are converted to ER vehicles with a small battery, S6 scenario energy system costs are reduced by approximately $8.5 \%$.

Due to the use of much smaller batteries, battery savings should also be taken into account; there are two important features for batteries: unit price and range. The range assumed, here, for a typical electric vehicle, today, requires a range of around $300 \mathrm{~km}$. Typically, the efficiency of an electric vehicle travels around 7 or $8 \mathrm{~km}$ for every kilowatthour battery. It is a relationship between how big is the vehicle's battery versus how much distance has to be traveled; for a $300 \mathrm{~km}$ range, we assume a $30 \mathrm{kWh}$ battery. 


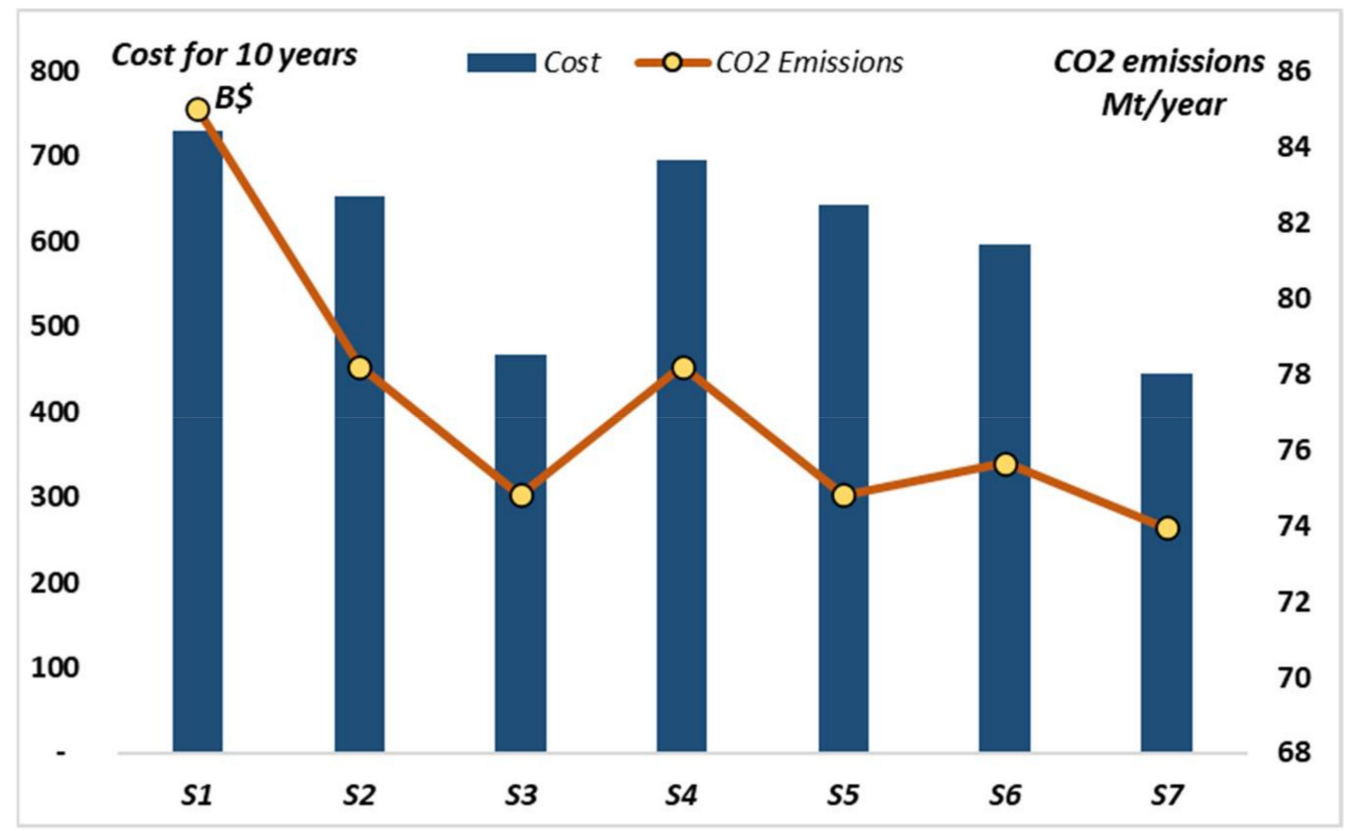

Figure 4 . The societal cost of the different scenarios for 15 years.

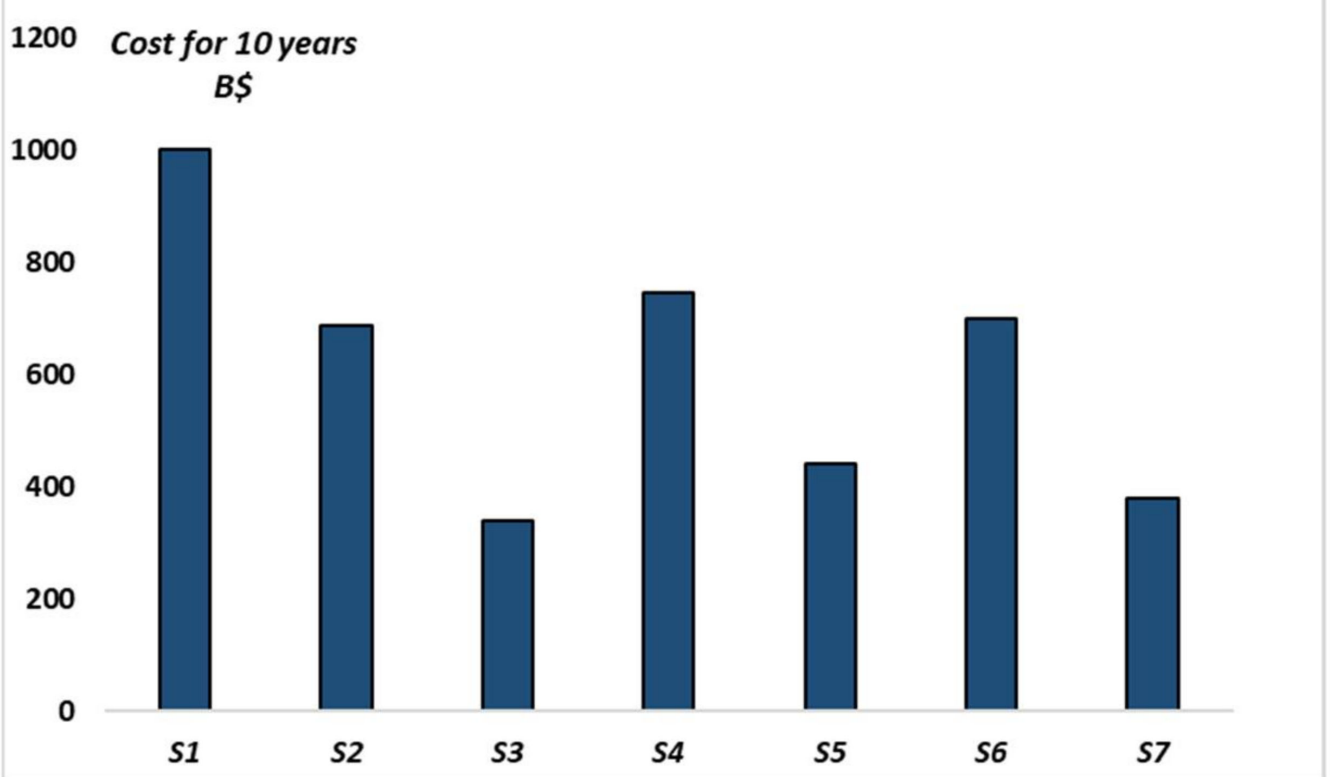

Figure 5. Various penetrations of ERS by the electricity and fuel costs, based on the year 2040.

The second really important thing is the unit price assumed to build such battery. In other words, how much should be paid per kilowatt-hour to make the battery? The reason that the unit price of batteries so important is because, today, batteries are produced at around $\$ 500$ per kilowatt-hour $[43,80]$. However, according to the literature, in the future many scientists predict that this can be reduced quite significantly. The lowest price ever estimated per kilowatt-hour is $\$ 100$. In this article, it is assumed the average of these, for this simple calculation, is $\$ 300$ per kilowatt-hour. The total contribution of the battery to the vehicle price is around $\$ 9000$. Although a range of $300 \mathrm{~km}$ is used in this study, when electric roads are activated, this $300-\mathrm{km}$ range will no longer be needed.

When ERS is put in place-assuming that the electric vehicles require only $100 \mathrm{~km}$ of range-that the battery price will be only $\$ 3000$. That means saving $\$ 6000$ for every electric vehicle sold. A relevant question is how many ER vehicles would need to be sold 
with smaller batteries to justify the construction of the ER versus not constructing the road and buying much bigger batteries. There are a lot of variations identified by more than 10 different companies that are currently trying to develop different forms of electric road technology. Although there are many uncertainties around this, the development price of about $\$ 1.5 \mathrm{M} / \mathrm{km}$ for one-way travel is assumed. Electric roads are a very affordable project to undertake as a society because of the savings the public receives from smaller batteries. We estimate a of cost $\$ 39$ B to construct the $26,011 \mathrm{~km}$ of electric roads needed for all Turkish highways. That is a huge number, but, to finish this story, one needs to consider how much money can be saved subsequently from electric roads, once built.

The construction cost of $\$ 18.2 \mathrm{~B}$ is divided by the $\$ 6000$ saved for every sold vehicle. It shows that 3 million electric vehicles with smaller batteries need to be sold and the the saved money used for the business of ERS rather than relying on bigger batteries.

Three million electric vehicles may seem ambitious, but in 2017 the number of cars sold in Turkey was 956.194 (excepting buses and trucks) [83,84]. If 1 million cars sold every year in Turkey were to be electric and have smaller batteries, within 3 years enough would be saved to electrify all highways and main roads in the country. If society stops spending money at the individual level on bigger batteries and instead spends money collectively on electric road infrastructure, a small battery and an electrified road infrastructure can cost less than a larger long-range battery.

The benefits do not only concern cost; there is a huge amount of additional benefit that comes with electric road infrastructure. The first benefit is, in theory, that ERS provides an unlimited range for electric vehicles. If an electric road is built from Istanbul to Ankara, the capital, then an electric vehicle can travel on one single charge from Istanbul to Ankara city. The other major benefit is enabling smaller batteries in electric vehicles. If electric roads are provided, then an electric vehicle will only need enough battery to reach the electric road rather than its final destination. That means the battery capacities can be significantly reduced and, therefore, significantly reduce the cost of electric vehicles. Finally, perhaps the most important benefit of ERS is that would enable us to electrify all forms of road transport, which means not only cars can be electrified, but also heavy-duty vehicles, such as buses and trucks. It will be a huge breakthrough in the sustainable transition because renewable energy resources, such as hydro, wind, and solar power, can be used to provide electricity to drive heavy-duty transport, which currently does not have an affordable and obvious sustainable alternative.

$\mathrm{CO}_{2}$ emissions are reduced in all scenarios that include increased penetration of battery electric vehicles and ER vehicles. Yet, it is accepted that the carbon emitted in the production of batteries and in the generation of consumed electricity of electric vehicles that do not produce $\mathrm{CO}_{2}$ while operating is greater than that of diesel vehicles. It takes 11 to 15 tons of $\mathrm{CO}_{2}$ to produce one battery-electric vehicle battery. Assuming that this battery is used to travel $15,000 \mathrm{~km}$ per year for 10 years, the $\mathrm{CO}_{2}$ emission per kilometer is 73 to $98 \mathrm{~g}$.

\subsection{The Sensitivity Analysis of 2040 Cost and Price Elasticity}

The following results are based on high battery and low fuel costs by 2021, but battery costs are expected to decrease significantly in the coming decades and fuel costs are expected to increase. Other costs, primarily renewable electricity costs, are expected to decrease, while $\mathrm{CO}_{2}$ prices are expected to increase. Each of these key trends will have a major impact on each scenario, so the same scenarios are repeated in this section using the forecasted 2040 costs in Table 5. The results using 2040 costs for the 2021 model with various battery and fuel levels are presented in Figure 5.

The cheapest scenario now comes with the conversion of all road vehicles to electric road technology, which reduces the cost of the energy system by almost $63 \%$ compared with the current scenario for the present. 
Table 5. Electric Vehicle and Battery Assumptions for 2021 and 2040.

\begin{tabular}{|c|c|c|c|c|c|}
\hline & & \multicolumn{4}{|c|}{ Type of Vehicle } \\
\hline & & \multicolumn{3}{|c|}{ Electric Road System } & \multirow{2}{*}{$\begin{array}{c}\text { Battery Electric } \\
\text { Cars and Vans }\end{array}$} \\
\hline & & Cars and Vans & Trucks & Buses & \\
\hline \multicolumn{2}{|c|}{ power capacity(kW/vehicle) } & 30 & 200 & 200 & 30 \\
\hline \multicolumn{2}{|l|}{ battery life (Years) } & 10 & 4 & 4 & 10 \\
\hline \multicolumn{2}{|c|}{ conversion cost to ERS (\$/vehicle) } & 2000 & 10000 & 10000 & - \\
\hline \multirow{2}{*}{ distance to cover with battery } & 2021 & $100 \mathrm{~km}$ & 100 km & $100 \mathrm{~km}$ & $300 \mathrm{~km}$ \\
\hline & 2040 & 100 km & 100 km & 100 km & $500 \mathrm{~km}$ \\
\hline \multirow{2}{*}{ battery unit cost } & 2021 & \multirow{2}{*}{\multicolumn{4}{|c|}{$\begin{array}{c}137 \$ / \mathrm{kWh} \\
73 \$ / \mathrm{kWh}\end{array}$}} \\
\hline & 2040 & & & & \\
\hline \multirow{2}{*}{ fuel cost } & 2021 & \multirow{2}{*}{\multicolumn{4}{|c|}{$\begin{array}{c}1.09 \$ / \mathrm{kWh} \\
1.5 \$ / \mathrm{kWh}\end{array}$}} \\
\hline & 2040 & & & & \\
\hline \multirow{2}{*}{ electricity cost } & 2021 & \multirow{2}{*}{\multicolumn{4}{|c|}{$\begin{array}{l}0.059 \$ / \mathrm{kWh} \\
0.050 \$ / \mathrm{kWh}\end{array}$}} \\
\hline & 2040 & & & & \\
\hline
\end{tabular}

\section{Conclusions}

The purpose of this work was to investigate whether roads can be developed and made smarter to promote greener, more electric vehicle traffic, and better energy distribution in the road area. One of the main goals of ERSs (electric road system) is to reduce vehicle costs by reducing the size of the battery required in electric vehicles. The ERS scenario developed for Turkey in this study requires the establishment of an ERS infrastructure of $26,011 \mathrm{~km}$ to reach the electric road at a distance of $70 \mathrm{~km}$ from anywhere in the country. The cost of implementing this infrastructure is approximately $\$ 19 \mathrm{~B}$, and the annual operating maintenance cost is approximately $\$ 286 \mathrm{M}$. However, these figures are relatively small when compared with battery and vehicle costs; it would be possible to install ERS in Turkey with 3 years of vehicle costs by the average of 2021 prices.

Consequently, ERS vehicles are cheaper than the corresponding battery electric vehicle scenario under all assumptions. This shows that, for Turkey, a combination of electric road infrastructure and smaller battery-electric cars is cheaper than bigger battery-electric cars. According to the results of the sensitivity analysis study, if the battery, fuel, and renewable energy costs improve as expected in the future, electrified roads will be much cheaper than oil.

To figure out all the pieces of the puzzle it is necessary to educate the market, deal with standardization, regulation, and to teach many students, from which to gain new knowledge. Additionally, the electric companies and the grid companies need to work together to figure out how best to deploy this technology in terms of the grid requirements at scale. What is interesting about this technology is how it fits into each different type or use case, such as for long-range vehicles. Long-haul trucking companies, traveling between states or between countries, want extended mileage. They are limited today by vehicles' battery capacities and how often they need to charge. Buses, too, operate on fixed routes; it makes perfect sense for them to be able to charge while driving and reduce downtime. The simulation study was limited to the main highways and so the demand for petroleum cars will be long lasting for all those that will not use frequently the electric roads.

This is the first study that analyzed the economic impact of the implementation of $26,011 \mathrm{~km}$ of electrified Turkish highways and divided roads. Therefore, many areas require further investigation, in terms of road types and installation, operation, and maintenance costs before concluding that electrified roads are the optimum solution, in practice. However, a deeper study is thus required regarding the costs of the various alternatives presented concerning the electrification of all the country's roads. When evaluating how to decarbonize the transportation sector, e-roads will present an important alternative to 
decision makers and investors, in the future. Various ERSs have been developed over the last 5 years, so more robust economic and technical data are likely to be available as various tests are concluded in the next decade.

Despite the potential limitations of this study, we have determined that electrified road systems are, under all assumptions, less expensive than the relevant battery electric vehicle scenario. In addition, a combination of ERS and smaller battery-electric vehicles are cheaper on their own than larger battery-electric cars. It can be concluded that the installation of an electric road system can improve the performance of vehicles in terms of battery degradation and energy consumption. However, research to determine whether a different approach to ERS layout should be the subject of future study, and will be published in a later paper. Moreover, it remains an open question whether this result can be transferred to a large area from small-population countries. Additionally, in future studies, different scenarios should be analyzed by taking into account international traffic flows in cross-border standardization.

Author Contributions: H.H.C.: conceptualization, supervision, data curation, writing-original draft; A.R.: formal analysis, resources, writing - review and editing, investigation; A.M.: visualization, funding acquisition, writing - review and editing, software. All authors have read and agreed to the published version of the manuscript.

Funding: This research received no external funding.

Institutional Review Board Statement: Not applicable.

Informed Consent Statement: Not applicable.

Data Availability Statement: The datasets generated during and/or analyzed in the current study are available from the corresponding author on reasonable request.

Conflicts of Interest: The authors declare no conflict of interest.

\section{References}

1. Williams, B. Breakthroughs in Science and Technology: Who Invented the Automobile? Encyclopaedia Britannica: London, UK, 2015; Volume 1, ISBN 978-1-62513-314-4.

2. Erşen, E.; Çelikpala, M. Turkey and the changing energy geopolitics of Eurasia. Energy Policy 2019, 128, 584-592. [CrossRef]

3. Kalehsar, O.S. Energy Insecurity in Turkey: Opportunities for Renewable Energy; Asian Development Bank Institute: Tokyo, Japan, 2019. Available online: http:/ / hdl.handle.net/10419/222825 (accessed on 21 December 2021).

4. Sozen, M.T. The Status of Renewable Energy Resources in Europe and Comparison of Turkey; Talcom: Kyiv, Ukraine, 2020; pp. 294-298. ISBN 978-617-7832-35-4.

5. Van Fan, Y.; Perry, S.; Klemeš, J.J.; Lee, C.T. A review on air emissions assessment: Transportation. J. Clean. Prod. 2018, 194, 673-684. [CrossRef]

6. Torres, R.R.; Benassi, R.B.; Martins, F.B.; Lapola, D.M. Projected impacts of 1.5 and $2{ }^{\circ} \mathrm{C}$ global warming on temperature and precipitation patterns in South America. Int. J. Climatol. 2021. [CrossRef]

7. Hasan, M.A.; Frame, D.J.; Chapman, R.; Archie, K.M. Costs and emissions: Comparing electric and petrol-powered cars in New Zealand. Transp. Res. Part D Transp. Environ. 2021, 90, 102671. [CrossRef]

8. Kobashi, T.; Yoshida, T.; Yamagata, Y.; Naito, K.; Pfenninger, S.; Say, K.; Takeda, Y.; Ahl, A.; Yarime, M.; Hara, K. On the potential of "Photovoltaics + Electric vehicles" for deep decarbonization of Kyoto's power systems: Techno-economic-social considerations. Appl. Energy 2020, 275, 115419. [CrossRef]

9. Wilson, L. Shades of Green: Electric Cars' Carbon Emissions around the Globe; Technical Report; ARRB Group Limited: Vermonth South, Australia, 2013; pp. 1-28.

10. Hildermeier, J.; Villareal, A. Shaping an emerging market for electric cars: How politics in France and Germany transform the European automotive industry. Eur. Rev. Ind. Econ. Policy 2012, 3, hal-03469137.

11. Jaffe, S. Vulnerable Links in the Lithium-Ion Battery Supply Chain. Joule 2017, 1, 225-228. [CrossRef]

12. Arora, A.; Niese, N.; Dreyer, E.; Waas, A.; Xie, A. Why Electric Cars Can't Come Fast Enough; Boston Consulting Group, 2021. Available online: https://www.bcg.com/publications/2021/why-evs-need-to-accelerate-their-market-penetration (accessed on 21 December 2021).

13. Sharif, A.; Baris-Tuzemen, O.; Uzuner, G.; Ozturk, I.; Sinha, A. Revisiting the role of renewable and non-renewable energy consumption on Turkey's ecological footprint: Evidence from Quantile ARDL approach. Sustain. Cities Soc. 2020, 57, 102138. [CrossRef] 
14. Situ, L. Electric vehicle development: The past, present \& future. In Proceedings of the 3rd International Conference on Power Electronics Systems and Applications (PESA), Digital Reference: K210509135, Hong Kong, China, 20-22 May 2009; IEEE: Manhattan, NY, USA, 2009; pp. 1-3.

15. Nordlund, A.; Jansson, J.; Westin, K. Acceptability of electric vehicle aimed measures: Effects of norm activation, perceived justice and effectiveness. Transp. Res. Part A Policy Pract. 2018, 117, 205-213. [CrossRef]

16. Soulopoulos, N. When will electric vehicles be cheaper than conventional vehicles? Bloomberg New Energy Finance. 12 April 2017. Available online: https://www.blogmotori.com/wp-content/uploads/2017/07/EV-Price-Parity-Report_BlogMotori_COM_ MobilitaSostenibile_IT.pdf (accessed on 21 December 2021).

17. Kim, S.; Lee, J.; Lee, C. Does driving range of electric vehicles influence electric vehicle adoption? Sustainability 2017,9 , 1783. [CrossRef]

18. Collin, R.; Miao, Y.; Yokochi, A.; Enjeti, P.; Von Jouanne, A. Advanced electric vehicle fast-charging technologies. Energies 2019, 12, 1839. [CrossRef]

19. Engel, H.; Hensley, R.; Knupfer, S.; Sahdev, S. Charging Ahead: Electric-Vehicle Infrastructure; McKinsey Co.: Atlanta, GA, USA, 2018; pp. 1-8.

20. Loeb, B.; Kockelman, K.M.; Liu, J. Shared autonomous electric vehicle (SAEV) operations across the Austin, Texas network with charging infrastructure decisions. Transp. Res. Part C Emerg. Technol. 2018, 89, 222-233. [CrossRef]

21. Sieklucki, G. An investigation into the induction motor of tesla model S vehicle. In Proceedings of the 2018 International Symposium on Electrical Machines (SME), Andrychow, Poland, 10-13 June 2018. [CrossRef]

22. Delang, C.O.; Cheng, W.T. Consumers' attitudes towards electric cars: A case study of Hong Kong. Transp. Res. Part D Transp. Environ. 2012, 17, 492-494. [CrossRef]

23. Forrest, K.; Mac Kinnon, M.; Tarroja, B.; Samuelsen, S. Estimating the technical feasibility of fuel cell and battery electric vehicles for the medium and heavy duty sectors in California. Appl. Energy 2020, 276, 115439. [CrossRef]

24. Skeete, J.P.; Wells, P.; Dong, X.; Heidrich, O.; Harper, G. Beyond the EVent horizon: Battery waste, recycling, and sustainability in the United Kingdom electric vehicle transition. Energy Res. Soc. Sci. 2020, 69, 101581. [CrossRef]

25. Nykvist, B.; Nilsson, M. Rapidly falling costs of battery packs for electric vehicles. Nat. Clim. Chang. 2015, 5, 329-332. [CrossRef]

26. Arora, S. Selection of thermal management system for modular battery packs of electric vehicles: A review of existing and emerging technologies. J. Power Sources 2018, 400, 621-640. [CrossRef]

27. Adegbohun, F.; von Jouanne, A.; Lee, K.Y. Autonomous battery swapping system and methodologies of electric vehicles. Energies 2019, 12, 667. [CrossRef]

28. Zeng, X.; Li, M.; Abd El-Hady, D.; Alshitari, W.; Al-Bogami, A.S.; Lu, J.; Amine, K. Commercialization of Lithium Battery Technologies for Electric Vehicles. Adv. Energy Mater. 2019, 9, 1900161. [CrossRef]

29. Schulte, J.; Ny, H. Electric road systems: Strategic stepping stone on the way towards sustainable freight transport? Sustainability 2018, 10, 1148. [CrossRef]

30. Connolly, D. Economic viability of electric roads compared to oil and batteries for all forms of road transport. Energy Strateg. Rev. 2017, 18, 235-249. [CrossRef]

31. Connolly, D. A Comparison between Oil, Battery Electric Costs; Aalborg Universitet: Copenhagen, Denmark, 2016 ; pp. 1-43.

32. Börjesson, M.; Johansson, M.; Kågeson, P. The economics of electric roads. Transp. Res. Part C Emerg. Technol. 2021, 125, 102990. [CrossRef]

33. Borén, S.; Nurhadi, L.; Ny, H.; Robèrt, K.H.; Broman, G.; Trygg, L. A strategic approach to sustainable transport system development-Part 2: The case of a vision for electric vehicle systems in southeast Sweden. J. Clean. Prod. 2017, 140, 62-71. [CrossRef]

34. Covic, G.A.; Member, S.; Boys, J.T.; Kissin, M.L.G.; Member, S.; Lu, H.G. A Three-Phase Inductive Power Transfer System for Roadway-Powered Vehicles. IEEE Trans. Ind. Electron. 2007, 54, 3370-3378. [CrossRef]

35. Villa, J.L.; Llombart, A.; Sanz, J.F.; Sallán, J. Practical development of a $5 \mathrm{~kW}$ ICPT system SS compensated with a large air gap. In Proceedings of the 2007 IEEE International Symposium on Industrial Electronics, Vigo, Spain, 4-7 June 2007; pp. 1219-1223. [CrossRef]

36. Sundelin, H.; Gustavsson, M.G.H.; Tongur, S. The maturity of electric road systems. In Proceedings of the 2016 International Conference on Electrical Systems for Aircraft, Railway, Ship Propulsion and Road Vehicles \& International Transportation Electrification Conference (ESARS-ITEC), Toulouse, France, 2-4 November 2016. [CrossRef]

37. Taljegard, M.; Göransson, L.; Odenberger, M.; Johnsson, F. Spacial and dynamic energy demand of the E39 highway—Implications on electrification options. Appl. Energy 2017, 195, 681-692. [CrossRef]

38. Stamati, T.E.; Bauer, P. On-road charging of electric vehicles. In Proceedings of the 2013 IEEE Transportation Electrification Conference and Expo (ITEC), Detroit, MI, USA, 16-19 June 2013. [CrossRef]

39. Chen, F.; Taylor, N.; Kringos, N. Electrification of roads: Opportunities and challenges. Appl. Energy 2015, 150, 109-119. [CrossRef]

40. Álvarez Fernández, R. A more realistic approach to electric vehicle contribution to greenhouse gas emissions in the city. J. Clean. Prod. 2018, 172, 949-959. [CrossRef]

41. Taljegard, M.; Thorson, L.; Odenberger, M.; Johnsson, F. Large-scale implementation of electric road systems: Associated costs and the impact on $\mathrm{CO}_{2}$ emissions. Int. J. Sustain. Transp. 2020, 14, 606-619. [CrossRef] 
42. Marques Soares, L. Economic Feasibility and Environmental Impact of Wireless Charging Techniques for Electric Ground Fleet in Airports; Rutgers University: Rutgers, NJ, USA, 2020. [CrossRef]

43. Nilsmo, O.; Wranne, E. An Economic Analysis of Electric Road System Technology; KTH Royal Institute of Technology, 2020. Available online: urn:nbn:se:kth:diva-281869 (accessed on 2 December 2021).

44. Domingues-Olavarría, G. Modeling, Optimization and Analysis of Electromobility Systems; Lund University: Lund, Sweden, 2018.

45. England, H. Feasibility Study: Powering Electric Vehicles on England's Major Roads; Highways England Company: Birmingham, UK, 2015.

46. Konstantinou, T.; Haddad, D.; Prasad, A.; Wright, E.; Gkritza, K.; Pekarek, S.; Haddock, J.E. Joint Transportation Feasibility Study and Design of In-Road Electric Vehicle Charging Technologies; Purdue University: West Lafayette, IN, USA, 2021. [CrossRef]

47. Özdemir, E.D. The Future Role of Alternative Powertrains and Fuels in the German Transport Sector: A Model Based Scenario Analysis with Respect to Technical, Economic and Environmental Aspects with a Focus on Road Transport. Ph.D. Thesis, Institut für Energiewirtschaft und Rationelle Energieanwendung (IER), University of Stuttgart, Stuttgart, Germany, 2012.

48. Goonan, T.G. Lithium Use in Batteries [Circular 1371]; United States Geological Survey: Reston, VA, USA, 2012; p. 22. Available online: https://pubs.usgs.gov/circ/1371/pdf/circ1371_508.pdf (accessed on 2 January 2022).

49. Mruzek, M.; Gajdáč, I.; Kučera, L'.; Barta, D. Analysis of Parameters Influencing Electric Vehicle Range. Procedia Eng. 2016, 134, 165-174. [CrossRef]

50. Sovacool, B.K.; Hirsh, R.F. Beyond batteries: An examination of the benefits and barriers to plug-in hybrid electric vehicles (PHEVs) and a vehicle-to-grid (V2G) transition. Energy Policy 2009, 37, 1095-1103. [CrossRef]

51. Rouissiya, M.; El Abbassi, I.; Amghar, B.; Jaafari, A.; Darcherif, A.-M.; Saad, A. Electrical energy wireless transfert: Application to electric roads. In Proceedings of the 15th International Conference on Electrical Machines, Drives and Power Systems (ELMA), Sofia, Bulgaria, 1-3 June 2017; CFP17L07-POD. IEEE: Manhattan, NY, USA, 2017; pp. 309-313.

52. Gil, A.; Taiber, J. A Literature Review in Dynamic Wireless Power Transfer for Electric Vehicles: Technology and Infrastructure Integration Challenges. In Sustainable Automotive Technologies; Wellnitz, J., Subic, A., Trufin, R., Eds.; Lecture Notes in Mobility; Springer: Cham, Switzerland, 2013; pp. 289-298. [CrossRef]

53. Venugopal, P.; Shekhar, A.; Visser, E.; Scheele, N.; Chandra Mouli, G.R.; Bauer, P.; Silvester, S. Roadway to self-healing highways with integrated wireless electric vehicle charging and sustainable energy harvesting technologies. Appl. Energy 2018, 212, 1226-1239. [CrossRef]

54. Sutopo, W.; Nizam, M.; Rahmawatie, B.; Fahma, F. A Review of Electric Vehicles Charging Standard Development: Study Case in Indonesia. In Proceedings of the 2018 5th International Conference on Electric Vehicular Technology (ICEVT), Surakarta, Indonesia, 30-31 October 2018; pp. 152-157. [CrossRef]

55. Domingues-Olavarría, G.; Márquez-Fernández, F.J.; Fyhr, P.; Reinap, A.; Alaküla, M. Electric roads: Analyzing the societal cost of electrifying all Danish road transport. World Electr. Veh. J. 2018, 9, 9. [CrossRef]

56. Sandberg, R. How to Reuse Consumed Batteries from Electric Vehicles; Chalmers University of Technology: Gothenburg, Sweden, 2019. Available online: https:/ / hdl.handle.net/20.500.12380/300168 (accessed on 21 December 2021).

57. Nordin, L.; McGarvey, T.; Ghafoori, E. Electric Road Systems: Impact on Road Construction, Maintenance and Operations; Swedish National Road and Transport Research Institute (VTI): Linköping, Sweden, 2020.

58. Lindgren, M. Electric road system technologies in Sweden: Gaining experience from research and demo facilities. In Transport Research Arena 2020; Finnish Transport and Communications Agency: Helsinki, Finland, 2020.

59. Hellgren, M.; Honeth, N. Efficiency of an AC Conductive In-Road Charging System for Electric Vehicles-Analysis of Pilot Project Data. SAE Int. J. Electrified Veh. 2020, 9, 27-40. [CrossRef]

60. Karlsson, A.; Alaküla, M. Conductive Electric Road Localization and Related Vehicle Power Control. World Electr. Veh. J. 2022, 13, 22. [CrossRef]

61. Sachse, T.; Gräbner, O. Intelligent Traffic Control and Optimization with Cooperative Systems on the eHighway; Electronic: Vienna, Austria, 2014; pp. 558-564. ISBN 978-1-4799-6729-2.

62. Ahmad, A.; Khan, Z.A.; Saad Alam, M.; Khateeb, S. A Review of the Electric Vehicle Charging Techniques, Standards, Progression and Evolution of EV Technologies in Germany. Smart Sci. 2018, 6, 36-53. [CrossRef]

63. Laporte, S.; Coquery, G.; Deniau, V. The Versailles-Satory charging infrastructure for Dynamic Wireless Power Transfer systems testing. In Proceedings of the 32nd Electric Vehicle Symposium (EVS32), Lyon, France, 19-22 May 2019; p. 12.

64. Wehrey, M.C. What's new with hybrid electric vehicles. IEEE Power Energy Mag. 2004, 2, 34-39. [CrossRef]

65. Allwood, J.; Horton, P.; Stephenson, S. Minus 45: Delivering the UK Government's Commitment to Cut Emissions by $45 \%$ from 2019 to 2030 Using Today's Technologies; UK Fires; University of Cambridge: Cambridge, UK, 2021. [CrossRef]

66. Ainalis, D.T.; Thorne, C.; Cebon, D. White Paper Decarbonising the UK's Long-Haul Road Freight at Minimum Economic Cost; The Centre for Sustainable Road Transport, 2020. Available online: https://www.csrf.ac.uk/2020/07/white-paper-long-haulfreight-electrification/ (accessed on 2 January 2022).

67. Gkritza, N. INDOT, Purdue to Develop Wireless Electric Vehicle Charging Solution for Highway Infrastructure; Purdue University: West Lafayette, IN, USA, 2021. Available online: https://engineering.purdue.edu/CE/AboutUs/News/Transportation_ Features/indot-purdue-to-develop-wireless-electric-vehicle-charging-solution-for-highway-infrastructure (accessed on 3 January 2022). 
68. Ghamami, M.; Zockaie, A.; Wang, J.; Miller, S. Electric Vehicle Charger Placement Optimization in Michigan: Phase I-Highways (Supplement I: Full Tourism Analysis). 2019. Available online: https://www.michigan.gov/documents/energy/TourismSupplementaryReport_662002_7.pdf (accessed on 4 January 2022).

69. Xu, J.; Liu, Z.; Jiang, H. Study on Application of Solar Energy in Highway. In Proceedings of the 2021 7th International Conference on Energy Materials and Environment Engineering (ICEMEE 2021), Zhangjiajie, China, 23-25 April 2021; EDP Sciences: Les Ulis, France, 2021; Volume 261. [CrossRef]

70. Squatriglia, C. Finland Proposes World's First "Green Highway"; WIRED: Boone, IA, USA, 2018; Available online: https://www. wired.com/2010/08/finland-green-highway/\#: \{\}:text=Oneofthebigquestions, chargingstationsandbiofuelstations (accessed on 4 January 2022).

71. Sasidharan, C.; Ray, A.; Das, S. Charging Infrastructure for Electric Taxi Fleets. In Electric Vehicle Integration in a Smart Microgrid Environment; CRC Press: Boca Raton, FL, USA, 2021; pp. 213-247. ISBN 978-0-367-42391-9.

72. Ulrich, L. Curbside cab charging: Wireless power tech keeps EVs on the go-[News]. IEEE Spectr. 2020, 57, 8-9. [CrossRef]

73. Yusuf, N.Q.; Prasetyo, E.B.; Kusumah, R.B. The Great Automotive Industry Transformation Following the Immediate Era of Electric Vehicles in Indonesia. Humanis 2021, 2, 692-704.

74. Lee, S.; Huh, J.; Park, C.; Choi, N.S.; Cho, G.H.; Rim, C.T. On-Line Electric Vehicle using inductive power transfer system. In Proceedings of the 2010 IEEE Energy Conversion Congress and Exposition, Atlanta, GA, USA, 12-16 September 2010; pp. 1598-1601. [CrossRef]

75. Motorlu Kara Taşıtları. Turkish Statistical Institute. Available online: https:/ / data.tuik.gov.tr/Bulten/Index?p=Motorlu-KaraTasitlari-Haziran-2021-37428 (accessed on 2 January 2022).

76. Bakirci, K.; Kirtiloglu, Y. Effect of climate change to solar energy potential: A case study in the Eastern Anatolia Region of Turkey. Environ. Sci. Pollut. Res. 2022, 29, 2839-2852. [CrossRef]

77. Road Network Information. General Directorate of Highways, 2021. Available online: https://www.kgm.gov.tr/Sayfalar/KGM/ SiteTr/Kurumsal/YolAgi.aspx (accessed on 10 January 2022).

78. Taşıt-Kilometre İstatistikleri 2019. Turkish Statistical Institute, 2021. Available online: https://data.tuik.gov.tr/Bulten/Index?p= Tasit-kilometre-Istatistikleri-2019-37409 (accessed on 11 January 2022).

79. Türkiye Trans-Avrupa Ulaştırması Karayolu Ağı (TEN-T). General Directorate of Highways, 2021. Available online: https: / / www.kgm.gov.tr/Sayfalar/KGM/SiteTr/Projeler/UluslararasiProjeler/Ten-T.aspx (accessed on 1 January 2022).

80. Temple, J. Why the Electric-Car Revolution May Take a Lot Longer than Expected. 2019. Available online: https://www. technologyreview.com/2019/11/19/65048/why-the-electric-car-revolution-may-take-a-lot-longer-than-expected/ (accessed on 12 January 2022).

81. Alfredsson, H.; von Essen, E. Cost Optimized Electrification of Lund City Bus Traffic Using Elonroad Electric Road System; Lund University: Lund, Sweden, 2018; Available online: http://lup.lub.lu.se/student-papers/record/8953325 (accessed on 7 January 2022).

82. Deichmann, J.I. Foreign Direct Investment in Turkey: Enhancing its Impact on Economic Development. Ekonomitek 2021, 10, 69-87.

83. Dogus 2017 Annual Report. 2018. Available online: https://www.dogusotomotiv.com.tr/faaliyet-raporu-2017/DGS-FRAT-2017.pdf (accessed on 12 January 2022).

84. Makine, Otomotiv, Elektrik-Elektronik Ürünleri Dairesi Başkanlığı, Otomotiv Sektör Raporu. 2021. Available online: https: / / ticaret.gov.tr/data/5b87000813b8761450e18d7b/Oto_Ana-Yan_Sanayi.pdf (accessed on 12 January 2022). 